\title{
Student Loan Debt and Financial Hardship among Young Adults
}

Min Zhan

Young adults are increasingly burdened with student loan debt. It is timely and important to examine how student loan debt influences their already vulnerable financial status. Is there a relationship between student loan debt and financial hardship among young adults? Do white young adults and minority young adults have different experiences in student loan debt and financial hardship? Analyzing data from the 2015 National Financial Capacity Study, the study results show that student loan debt was negatively related to several measures of financial hardship: difficulty in paying bills, difficulty in meeting health care needs, and delay in the payment of home mortgage. After controlling for a range of socioeconomic factors and financial literacy, minority young adults were more likely to experience financial hardship than their white counterparts. In addition, it appears that student loan debt had additional negative impact on late payment of home mortgage among minority young adults. Policy and practice implications are discussed.

Keywords: financial hardship, financial literacy, race, student loan debt, young adults

\section{Race, Student Loan Debt, and Financial Hardship among Young Adults}

The rising student loan debt in the last decades (Institute for College Access and Success, 2015; Payea, Baum, \& Kurose, 2013) has raised serious concerns regarding its consequences on the financial well-being of loan holders. Evidence shows that the burden of education loans is particularly prominent among the households headed by young adults; for example, over 40 percent of all households headed by individuals younger than age 35 have outstanding student debts (Fry, 2012; Ratcliffe \& McKernan, 2013). Even more concerning is that many young adult borrowers are heavily burdened with student loans (Fry, Parker, \&

Min Zhan, Professor, School of Social Work, University of Illinois at Urbana-Champaign, 1010 West Nevada Street, Urbana, IL 61801, USA, mzhan@illinois.edu, Phone: 217-244-5252

(C) 2020 International Consortium for Social Development 
Rohal, 2014), and they face great challenges in repaying their debts. For example, reported numbers of loan delinquency, loan default, and bankruptcy among borrowers have sharply increased in recent years (Brown, Haughwout, Lee, Scally, \& van der Klaauw, 2014; Gicheva \& Thompson, 2015). As such, young adults with student loan debts are more likely to face additional financial challenges, especially given the fact that they are already financially vulnerable (Emmons, 2012; Steuerle, McKernan, Ratcliffe, \& Zhang, 2013), compared to other age groups.

Along with the widespread student loan burdens among young adults, inequality in financial well-being has also widened across age groups. Young adults were already falling behind before the economic recession in 2009, and they were among the hardest hit by the same (Emmons, 2012; Steuerle et al., 2013). As an example, the average net worth of a household headed by a person aged under 35 years was nearly 50 times less than that of a household headed by someone aged 65 or older right after the economic recession (Taylor et al., 2011). The financial vulnerability among young adults was also reflected in other indicators. A recent study (Karpman, Zuckerman, \& Gonzalez, 2018) reported that young adults (18-34) were more likely (43 percent) to experience material hardship, which was measured as having difficulty in meeting basic needs, including housing, food, utilities, and health care needs, than the other two age groups (40 percent for those aged between 35 and 49 years, and 34 percent for those aged between 50 and 64 years).

As such, emerging studies have examined how education loans are related to young adults' financial well-being, including earning capacity (e.g., Hiltonsmith, 2013) and various indicators of wealth accumulation, such as home and vehicle ownership and value of net worth (e.g., Zhan \& Xiang, 2018). However, limited research has explored how student loan is related to financial hardship among young adults, and how such impact might differ between white, non-Hispanic (referred to as "white young adults") and all others (referred to as "minority young adults" in this study). Here, we explore two major research questions. First, are student loan debts and race associated with measures of financial hardship among young adults? Second, is the association between student loan debt and financial hardship different between white young adults and minority young adults? We hypothesize that having student loan debts is negatively related to financial hardship among young adults because the presence of student loans may cause budget constraints and financial stress. We also hypothesize that student loan debt may pose greater risks for minority borrowers because of their already vulnerable socioeconomic status, compared to their white counterparts.

This research builds on current literature in several important ways. First, while studies started examining the impact of student loans on income and wealth accumulation among young adults (Fry et al., 2014; Hiltonsmith, 2013; Zhan, Xiang, \& Elliott, 2016), how student loan debt is related to financial hardship has received little attention. As a measure of ability to meet basic needs, 
financial hardships are also influenced by other factors, in addition to income and wealth (Heflin, Sandberg, \& Rafail, 2009). Thus, financial hardship provides a more direct and broader assessment of young adults' financial status.

Second, previous research has not explored whether the associations of student loans with financial hardship are different for white young adults and minority young adults. Such variations could be attributed to higher levels of loan burden, less availability of parental economic support, lower graduation rate, and higher rate of unemployment among minority young adults (Baum \& Steele, 2010; Kerby, 2013). Investigating possible differential links between student loans and financial hardship among white young adults and minority young adults helps develop more targeted policies and practices to address issues of financial hardship.

Third, this study includes several measures of financial hardships: difficulty in paying bills/covering expenses; difficulty in meeting health care needs (including unpaid medical bills, skipped prescription and medical appointment due to costs), and being late on home mortgage and student loan payments. These measures capture multiple dimensions of financial hardship, which allows a thorough examination of financial hardship among young adults.

And finally, in addition to socioeconomic factors, this study also incorporates several other covariates that may have an important influence on financial hardship, including financial literacy, health insurance coverage, and availability of emergency funds. The inclusion of these variables helps better understand the unique contribution of student loan debt and race to financial hardship among young adults.

\section{Prior Scholarship}

\section{Rationale}

Student loan debt may be related to financial hardship by imposing budget constraints and financial stress among young adults. Evidence shows that among young adults (under the age of 40), debt from student loans is associated with the likelihood of having other types of debt, and the total debt among collegeeducated young households is nearly twice that of their counterparts without student loan debt, and the gap is even sharper among less-educated households (Fry et al., 2014). Burdened with heavy debt, a study finds that over 40 percent of student loan holders have been delinquent on their loan or have defaulted on it (Cunningham \& Kienzl, 2011), and minority loan borrowers have even higher default rates (Kerby, 2013). Among all consumer debt products, delinquency rate was the highest for student loans (Sanchez \& Zhu, 2015). As such, student loans pose serious financial constraints among borrowers. For example, the median debt-to-income ratio among college graduates with debt from loans was as high as 205 percent (compared to 108 percent among their counterparts without 
education loans) (Mishory \& O'Sullivan, 2012). It was not surprising that student loan was linked to higher levels of financial stress and anxiety (Andruska, Hogarth, Fletcher, Forbes, \& Wohlgemuth, 2014; Archuleta, Dale, \& Spann, 2013; Heckman, Lim, \& Montalto, 2014).

The budget constraints and financial stress experienced by minority loan holders may be disproportionately higher. First of all, evidence shows that minority students are more likely to take loans to finance college expenses. They also report greater difficulties with and concerns about repayment (Baum \& O'Malley, 2003; Ratcliffe \& McKernan, 2013). For example, researchers consistently found that minority students were more likely to default than their white peers (Cho, $\mathrm{Xu}, \&$ Kiss, 2015). Second, due to racial and ethnic disparities in income and assets (e.g., Bricker, Kennickell, Moore, \& Sabelhaus, 2012; Kochhar, Fry, \& Taylor, 2011), young adults from minority families are less likely to receive financial support from their parents. The survey by Sallie Mae (2016) indicated that during the academic year 2015-2016, in general, parent income and savings funded 29 percent of college costs; however, there is evidence that higher income, college education, and white parents were more likely to help pay for their children's college education (Cha, Weagley, \& Reynolds, 2005; Houle, 2014; McCabe \& Jackson, 2016). Third, studies indicate that minority students receive less of an economic return from their college education than do their white counterparts (e.g., Crissey, 2009). For example, black college graduates were mostly likely to be unemployed in 2013 (Jones \& Schmitt, 2014), and the risk of losing a job during an economic recession is greater for them as well (Austin, 2009). Therefore, student loans could pose greater risks for these borrowers.

\section{Empirical Evidence: Student Loan Debt and Financial Well-Being}

\section{Student Loans and Wealth}

Existing studies have examined how student loan debt is related to different indicators of postcollege financial well-being. Studies consistently report that having student loans compromises various indicators of wealth accumulation, both short term and long term. An analysis of the Survey of Consumer Finances indicates that average net worth (total values of assets minus total values of debt) of college-educated young adults (aged 40 or younger) without education debt was seven times greater than those with student loans (Fry et al., 2014). The study by Zhan et al. (2016) utilized a treatment-effect model that better controls selection bias to examine the link between student loans and multiple measures of wealth accumulation. Their findings indicate that having outstanding student loans upon leaving college is negatively related to postcollege net worth, financial assets, nonfinancial assets, and the value of primary housing.

Studies also projected possible long-term loss of savings due to student loan debt. Egoian (2013) estimated that a bachelor degree holder with a median 
student debt of $\$ 23,300$ would have $\$ 115,096$ less in retirement savings at age 73, compared to his counterpart without such debt. By analyzing Survey of Consumer Finances data, Hiltonsmith (2013) projected that an average education loan of $\$ 53,000$ leads to a lifetime loss of $\$ 200,000$ in retirement savings.

There is also some evidence that student loan debt might be associated with reduced ownership rates and delayed purchase of homes and vehicles (Brown \& Caldwell, 2013; Houle \& Berger, 2015; Shand, 2007; Stone, Van Horn, \& Zukin, 2012). The study by Houle and Berger (2015) found the inverse associations between student loan debt with home ownership status, as well as with mortgage acquisition and the amount of mortgage debt, among a national representative sample of young adult home owners, but the effect size of their findings were modest.

\section{Financial Hardship}

Studies have indicated that student loans are linked to various measures of financial hardship (e.g., Akers, 2014; Bricker \& Thompson, 2016; Despard et al., 2016; Gicheva \& Thompson, 2015). The study by Bricker and Thompson (2016) indicated that households with student loan debt were more likely to experience late bill payment and denied credit, and they had higher payment-to-income ratio. Gicheva and Thompson (2015) reported that more student loan debt was also associated with higher likelihood of declaring bankruptcy in addition to being credit constrained and more likely to experience difficulty staying current on payments. The study by Despard et al. (2016) examined the link between student loan debt and more comprehensive measures of financial hardship among low- and moderate-income households. Their study findings indicate that having student loan debts increased the likelihood of material hardship (cannot afford certain types of food, late payment, etc.), health care hardship (cannot afford to see a doctor or go to hospital, etc.), and financial difficulty (experiencing a bank overdraft, a credit card being declined, etc.). In addition, college graduates experienced lower odds of hardship, compared to their nongraduate peers.

\section{This Study}

The evidence reviewed above indicates that student loan debt compromises wealth accumulation and is related to increased financial hardship among young adults. However, existing research has not specifically examined how student loan debt may influence financial hardship differently for white young adults versus minority young adults. There is some evidence that student loans have additional negative links with wealth accumulation among minority young adults (Houle \& Berger, 2015; Zhan et al., 2016). Thus, it is worthwhile to explore possible differences in the relationship between student loans and financial hardship, so that corresponding policies and practices could be developed. 


\section{Methods}

\section{Data and Sample}

The data for this study are from the 2015 National Financial Capacity Study (NFCS), a triannual survey that was initiated in 2009 and funded by Financial Investor Regulatory Authority (FINRA) Investor Education Foundation. The participants for the 2015 NFCS survey were recruited online through three established panels in the United States: Survey Sampling International (SSI), EMI Online Research Solutions, and Research Now. The survey used nonprobability quota sampling with 500 samples per state and about 1,000 samples each in the four large states of California, Illinois, New York, and Texas. A total of over 27,000 adults completed the survey in 2015, with a response rate of nearly 40 percent. The sample for this study included 5,013 respondents in the age group of 24-35 years (young adults), including 3,165 white young adults and 1,848 minority young adults.

\section{Variables and Measures}

\section{Outcome Variables: Financial Hardship}

Young adults' experience of financial hardships is measured using four categories of indicators. The first indicator is whether or not a respondent experiences difficulty to cover his/her expenses and pay all their bills in a typical month ( 1 = somewhat or very difficult; $0=$ not at all difficult). The second measure covers hardship related to health care, more specifically whether or not a respondent had any unpaid bills from a health care or medical service provider at the time of interview, or they had to skip treatment or prescription for medicine due to cost in the last 12 months. A binary measure was recoded, which indicates whether or not a young adult experiences any of these hardships related to health care ( $1=$ Yes, $0=$ No). The third indicator is whether or a not a respondent was late with mortgage payments in the past 12 months $(1=$ Yes, $0=$ No). And the fourth measure is whether or not a respondent was late with a student loan payment in the past 12 months $(1=$ Yes, $0=$ no $)$.

\section{Independent Variables}

The two primary variables of interest are a respondent's race (white, non-Hispanic vs. others, "minority") and whether or not a respondent had any outstanding student loans at the time of interview.

Young adults' other demographic characteristics include their sex (male vs. female), marital status (married vs. not married), and whether having dependent children (yes or no). Their socioeconomic characteristics include their annual household income (less than $\$ 35,000$, at least $\$ 35,000$ but less than $\$ 75,000$, 
and at least $\$ 75,000$ and above), educational status (some college education or less, bachelor degree or above), employment status (employed vs. unemployed), checking account ownership (yes or no), savings account (money market account, CDs) ownership, home ownership (yes or no), health insurance coverage (yes or no), and whether a respondent set aside emergency funds that would cover expenses for 3 months, in case of emergencies (yes or no). A respondent's level of financial knowledge is also included. Financial knowledge is measured with an individual's cognitive dimensions or objective knowledge about financial concepts. This is measured by a series of six questions, which objectively test a person's knowledge of certain financial aspects, such as compound interest, inflation, interest rates and bond prices, mortgages, and stock and mutual fund. A new financial knowledge measure was created with these six questions, with "low financial literacy" (zero to three correct answers) and "high financial literacy" (four to six correct answers).

\section{Statistical Analysis}

Several major analyses were conducted. First, descriptive analyses were conducted to present sample characteristics by race (white young adults vs. minority young adults). Chi-square analyses were further conducted to examine if sample characteristics, including measures of financial hardships, vary by race. Second, more detailed analyses were run to examine how indicators of financial hardship vary by both race and student loan status. Third, regression analyses were conducted to examine how race and student loan debt are related to the indicators of financial hardships, after controlling other demographic and socioeconomic variables in the model. Since all four measures of financial hardships are binary (yes or no), four logistics regression models will be conducted.

\section{Results}

\section{Sample Characteristics}

Table 1 provides descriptive statistics for the study sample by race. The sample of 5,013 respondents included 3,165 white young adults (63 percent) and 1,848 minority young adults ( 37 percent). Not surprisingly, a number of sample characteristics were statistically different in these two groups. Compared to minority young adults, white young adults were more likely to be married (56 percent vs. 46 percent). A higher proportion of white young adults had a bachelor (or a higher) degree, were employed, and had higher household income. They also were more likely to have a bank account, home ownership, emergency fund, and health insurance coverage. In addition, a larger percentage of white young adults had higher levels of financial knowledge. In terms of the four measures of financial hardships, minority young adults were more likely to have difficulty in paying bills and covering expenses, and they had higher risks of being late on mortgage and 
Table 1 Sample characteristics by race $(N=5,013)$

\begin{tabular}{|c|c|c|c|}
\hline Variables & $\begin{array}{c}\text { Whites } \\
(N=3,165)\end{array}$ & $\begin{array}{c}\text { Minorities } \\
(N=1,848)\end{array}$ & Chi-square \\
\hline \multicolumn{4}{|l|}{ Gender } \\
\hline Female & $57 \%$ & $56 \%$ & $p=0.40$ \\
\hline \multicolumn{4}{|l|}{ Marital status } \\
\hline Married & $56 \%$ & $46 \%$ & $* * * p=0.001$ \\
\hline Having dependent children & $53 \%$ & $52 \%$ & $p=0.31$ \\
\hline \multicolumn{4}{|l|}{ Education } \\
\hline \multicolumn{4}{|l|}{ Some college education or less } \\
\hline Bachelor's degree and above & $47 \%$ & $44 \%$ & ${ }^{*} p=0.05$ \\
\hline \multicolumn{4}{|l|}{ Employment status } \\
\hline Employed & $74 \%$ & $71 \%$ & ${ }^{*} p=0.02$ \\
\hline \multicolumn{4}{|l|}{ Income } \\
\hline Less than $\$ 35,000$ & $30 \%$ & $36 \%$ & $* * * p=0.001$ \\
\hline$\geq \$ 35,000$ but $<\$ 75,000$ & $43 \%$ & $41 \%$ & \\
\hline$\geq \$ 75,000$ & $27 \%$ & $23 \%$ & \\
\hline Having health insurance coverage & $86 \%$ & $82 \%$ & $* * * p=0.001$ \\
\hline Checking account ownership & $93 \%$ & $91 \%$ & ${ }^{\star} p=0.02$ \\
\hline Savings and other account ownership & $79 \%$ & $77 \%$ & ${ }^{*} p=0.04$ \\
\hline Home ownership & $53 \%$ & $40 \%$ & $* * * p=0.001$ \\
\hline Having emergency fund & $43 \%$ & $45 \%$ & $+p=0.07$ \\
\hline \multicolumn{4}{|l|}{ Financial knowledge } \\
\hline High financial literacy scores & $40 \%$ & $29 \%$ & $* * * p=0.001$ \\
\hline Having student loan debt & $48 \%$ & $46 \%$ & $p=0.15$ \\
\hline \multicolumn{4}{|l|}{ Financial hardship } \\
\hline Having difficulty paying bills & $54 \%$ & $59 \%$ & $* * p=0.01$ \\
\hline Having difficulty meeting health care needs & $47 \%$ & $46 \%$ & $p=0.21$ \\
\hline Late on mortgage payment (among home owners) & $20 \%$ & $31 \%$ & $* * * p=0.001$ \\
\hline Late on student loan payment (among loan holders) & $25 \%$ & $33 \%$ & $* * * p=0.001$ \\
\hline
\end{tabular}

$+p<0.10,{ }^{*} p<0.05,{ }^{* *} p<0.01 ;{ }^{* * *} p<0.001$.

student loan payment. The two groups were not statistically different in meeting needs related to health care.

Financial Hardships by Race and Student Loan Status

Financial hardships of young adults were further examined by their race and student loan status (Table 2). The young adults with student loan debt were more likely to have difficulty in paying bills and covering their expenses, within each of the two groups. Those with student loan debt were also more vulnerable to being late on home mortgage payment. For example, among white young adults, 27 percent of those with loans had instances of late payment, compared to 12 percent among those without loan; and among minority young adults, the percentages were 47 percent and 16 percent, respectively. 
Table 2 Financial hardships by race and student loan debt

\begin{tabular}{|c|c|c|c|c|}
\hline \multirow[t]{2}{*}{ Financial hardship } & \multicolumn{2}{|c|}{ Whites } & \multicolumn{2}{|c|}{ Minorities } \\
\hline & With loans & Without loans & With loans & Without loans \\
\hline Having difficulty paying bills & $59 \%$ & $48 \%$ & $64 \%$ & $54 \%$ \\
\hline $\begin{array}{l}\text { Having difficulty meeting } \\
\text { health care needs }\end{array}$ & $55 \%$ & $38 \%$ & $56 \%$ & $37 \%$ \\
\hline $\begin{array}{l}\text { Late on mortgage payment } \\
\text { (among home owners) }\end{array}$ & $27 \%$ & $12 \%$ & $47 \%$ & $16 \%$ \\
\hline $\begin{array}{l}\text { Late on student loan payment } \\
\text { (among loan holders) }\end{array}$ & $25 \%$ & N.A. & $33 \%$ & N.A. \\
\hline
\end{tabular}

Results from the Logistics Regressions

Table 3 presents the results from logistic regressions on the four indicators of financial hardships. Results indicate that, after controlling for all other factors in the model, minority young adults were more likely to experience difficulty in covering expenses and paying all bills as well as in meeting health care needs due to cost. They were also more likely to being late on home mortgage and student loan payment (odds ratios ranged from 1.1 to 1.6).

Results also indicate that young adults who had student loan debt were more likely to experience financial hardships. For example, the young adults who had student loan debt were about 0.8 times more likely to have difficulty in paying bills, 1.3 times more likely to have financial difficulty in meeting health care needs, and 2.3 times more likely to being late on mortgage payment.

Among demographic and socioeconomic factors, female young adults and those with dependent children were more vulnerable to financial hardships. On the other hand, those who had at least a bachelor's degree, had higher income, and had health insurance coverage were likely to suffer financial hardships. Similarly, young adults who owned savings accounts, and those who had emergency savings were less likely to experience financial hardships. Higher levels of financial knowledge were also important factors in protecting young adults from financial hardships. However, young adults who were employed were more likely to be late on mortgage and student loan payment, and the home owners were more likely to be late on loan payment as well.

\section{Discussion, Limitations, and Implications}

\section{Discussion}

This study investigates the association between student loan debt and financial hardship among a nationally representative sample of young adults. Financial hardship was common among the study sample. Over half of young adults experienced difficulty in paying bills on time, and nearly half of them also struggled 


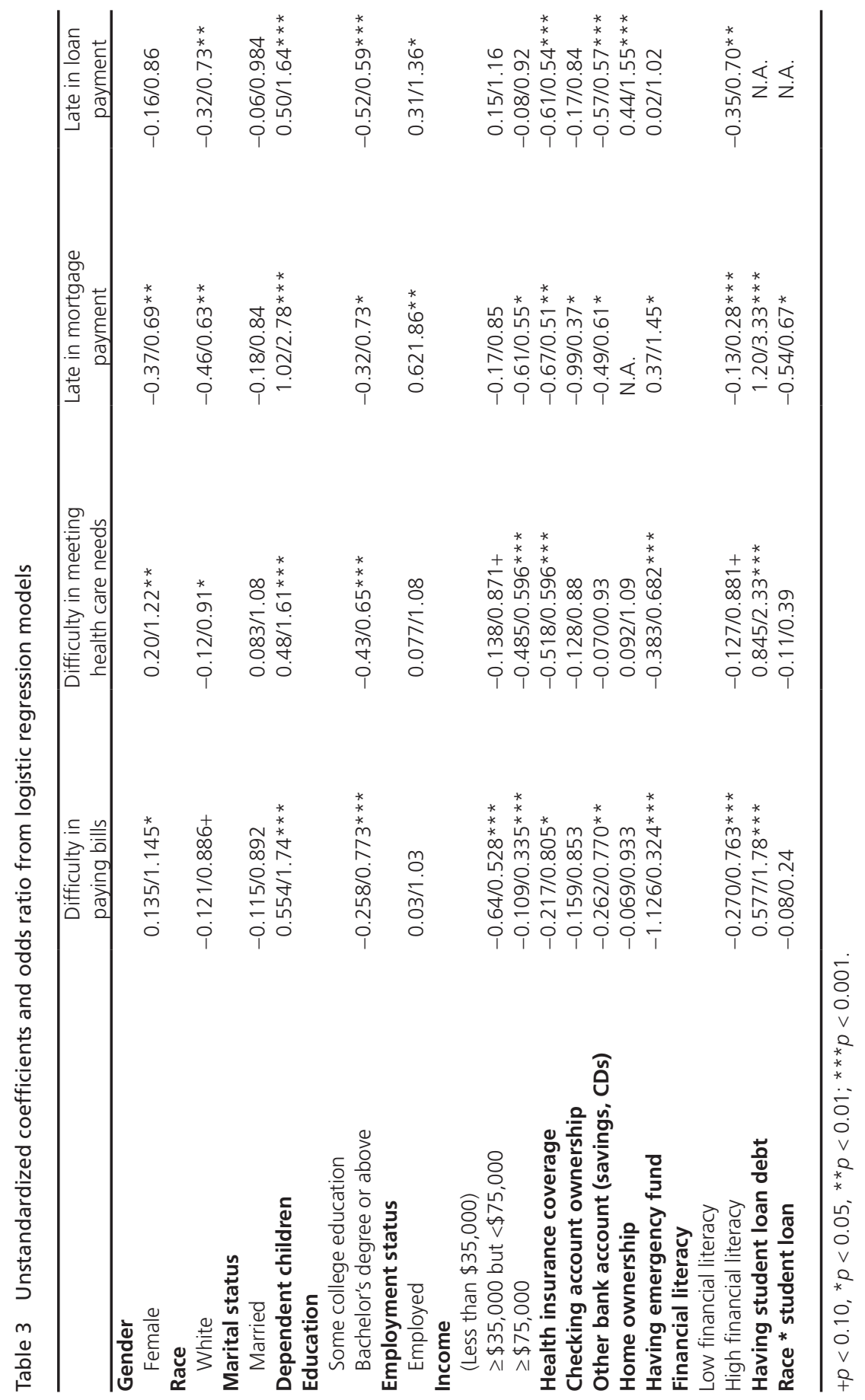


in meeting basic health care needs. About a quarter of home owners were late on mortgage payment, and nearly one-third of those who had student loans were late on student loan payment. Although common among the entire sample, financial hardship was much worse among minority young adults and those who had student loan debt.

More specifically, this research examines two major research questions. First, it investigates the relationship of student loans and race with different measures of financial hardship among young adults. After controlling for a range of socioeconomic characteristics, study findings indicate that having student loans was negatively related to difficulty in paying bills, meeting needs related to health care, and being late on home mortgage payment. This result is consistent with previous findings (Bricker \& Thompson, 2016; Despard et al., 2016; Gicheva \& Thompson, 2015). The findings from this study further contribute to the knowledge in the literature, since this study uses various measures of financial hardship that indicates a young adult's financial ability to meet basic needs in utilities, housing, health care, and other areas. Contributing to the literature (e.g., Karpman et al., 2018), the study also finds that after taking student loans and a range of socioeconomic characteristics into consideration, minority young adults were more likely to experience all four types of financial hardship than their white counterparts. In other words, the disadvantages of being a minority persist. Thus, future research is needed to further explore what additional factors may help explain the different experiences in financial hardship between white young adults and minority young adults.

This study further explores the second research question, that is, whether the association between student loan debt and financial hardship differs between white young adults and minority young adults. The significant interaction between race and having outstanding student loans in their influence on mortgage payment indicates that student loan debt had an additional, negative impact, and that impact differs from the main negative effects of race and student loan debt. This result is consistent with our second hypothesis. As we mentioned earlier, minority young adults are more likely to have education loans than their white counterparts and their loan burden would be much higher (measured with loan-to-income ratio and loan-to-financial assets ratio), which may help explain why the effects of loans are stronger for minority young adults. It provides evidence that having education loans may further magnify the already widening financial status between white young adults and minority young adults. However, interaction between race and student loan was not statistically significant in their influence on difficulty in paying bills or meeting health care needs.

As one of the few studies that examines the relationship between student loans and other factors with financial hardship, some of the results from covariates are worthy of mention. Among demographic characteristics, female young adults and those with dependent children were more likely to have financial hardship, which is consistent with results from previous research (e.g., Karpman et al., 2018). The probability of experiencing all four measures of hardship was 
higher for young adults with a bachelor's degree than for those without a 4-year degree, and the differences persist in results from analyses that control for education loans as well as other variables. This finding highlights the importance of a college degree in improving financial statistics among young adults, although student loan increases financial hardship. Household income and having health insurance also helped reduce young adults' financial hardship, highlighting the importance of availability of economic status and health insurance coverage. These findings on education, income, and health insurance are consistent with the research findings on the relationship between student loans and wealth accumulation (e.g., Zhan \& Sinha, 2019).

Another interesting finding is that it seems financial capacity-building among young adults, which includes both access to savings and financial literacy, were negatively related to financial hardship among young adults. More specifically, young adults with higher levels of financial literacy were less likely to experience all four indicators of financial hardship, compared to those with lower levels of financial literacy. Moreover, young adults who had savings accounts and emergency savings were also less likely to experience hardship. These findings support the notion that financial capacity-building helps enhance financial well-being (Sherraden, 2010), thus reducing financial hardship.

\section{Limitations}

A few limitations are noteworthy and point to useful directions for future research. First, the study is not an experimental research or a longitudinal study. Although the study utilizes a well-regarded national data set and controls for a number of important factors that may influence financial hardship, it is impossible to fully rule out alternative explanations for the findings. Second, as the data were collected through self-administered questionnaires on a website, there are high chances of selection bias of the participants; in addition, the low response rate of the survey further indicates that the responses could be biased. Third, this study does not examine the possible mechanisms through which student loan debt and race influence financial hardship. Future analyses in this regard will help develop a new knowledge base and theoretical frameworks as well as effective policy and practice interventions.

\section{Implications}

In a period of rising education loan burdens among young adults and the marked financial challenges they face, it is critical to examine the link between education loans and financial hardship in this population. The current study provides evidences that having student loans present different types of financial hardships for young adults. In addition, it appears that student loan debt might have additional negative links with financial hardship for minority young adults. Therefore, addressing college students' financial needs with additional education loans and 
other types of credit may be counterproductive and may also magnify racial/ ethnic disparities in financial status among young adults.

Alternative strategies to address college financial needs are needed. The cost burden of college tuition has shifted more toward the student and their family in recent decades, versus assistance from the state or the federal government. Therefore, it is critical to promote federal and state investment in affordable higher education, thus increasing access of students to need-based student aid and decreasing their reliance on student loans. For example, Pell Grants are perhaps the most effective investment by the federal government in helping college access and success of low- and moderate-income students. However, the purchasing power of Pell Grants has declined over time; therefore, improving Pell Grants can help reduce minority and low-income students' reliance on loans (Ratcliffe \& McKernan, 2013).

Given the consideration that minority students are more likely to be the victims of financial fraud (Ramirez, Ohlhausen, \& McSweeny, 2016), it is equally important to strengthen policies that help loan holders to avoid fraud and abuse of student loan services by receiving accurate and timely billing statements and available repayment options (Illinois Asset Building Group, 2017). Also, evidence shows that young adults' participation in this Income-Based Repayment Plan can help them save and build financial wealth (Zhan \& Sinha, 2019). However, many loan borrowers are unware that participation of Income-Based Repayment (IRB) plan can be used to help them avoid default or improve their credit standing (Herbst, 2018). Therefore, increasing the knowledge of this program among young adults, especially minority young adults, and expanding the program's eligibility and streamlining the application process will be helpful.

Another important finding from this study is that minority young adults face particular financial challenges, compared to their white peers. In addition to student loan, they face challenges due to their lower education status and income, as well as their disadvantages in the financial market experiences (including less access to mainstream bank account and lower levels of financial literacy). Therefore, strategies that help improve graduation rates of minority college students and increase their access to mainstream financial services may help reduce their financial hardship.

The study findings also show that financial literacy is another important buffer to financial hardship. However, evidence shows that young adults, including college graduates, have demonstrated lack of financial knowledge and skills (Avard, Manton, English, \& Walker, 2005; Chen \& Volpe, 2002; Robb, 2011; Sinha, Tan, \& Zhan, 2018). Therefore, it is critical to invest more in the financial education efforts among children and young adults. There is evidence that young adults are less likely to take advantage of financial education opportunities than other age groups (McDaniel, Montalto, Ashton, Duckett, \& Crot, 2014; Mottola, 2014). Perhaps, customizing the programs based on the diverse needs of young adults, instead of designing/implementing one-size-fits-all programs, may help improve program participation. Given the lower levels of financial literacy among minority 
young adults (Sinha et al., 2018), and the lower returns of financial education among them (Al-Bahrani, Weathers, \& Patel, 2019), it is even more critical to design financial education programs that are specially designed to meet their needs.

\section{References}

Akers, B. (2014). How much is too much? Evidence on financial well-being and student loan debt (Report, American Enterprise Institute Series on Reinventing Financial Aid). Washington, DC: American Enterprise Institute. Retrieved from http://www.aei.org/files/2014/05/14/-how-much-is-too-much_ 100837569045.pdf

Al-Bahrani, A., Weathers, J., \& Patel, D. (2019). Racial differences in the returns to financial literacy education. The Journal of Consumer Affairs, 53(2), 572599. doi:10.1111/joca.12205

Andruska, E. A., Hogarth, J., Fletcher, C. N., Forbes, G., \& Wohlgemuth, D. (2014). Do you know what you owe? Students' understanding of their student loans. Journal of Student Financial Aid, 44(2), 124-148.

Archuleta, K. L., Dale, A., \& Spann, S. M. (2013). College students and financial distress: Exploring debt, financial satisfaction, and financial anxiety. Journal of Financial Counseling and Planning, 24(2), 50-62.

Austin, A. (2009, April 22). Among college-educated, African Americans hardest hit by unemployment (Economic Snapshot). Washington, DC: Economic Policy Institute. Retrieved from http://www.epi.org/economic_snapshots/entry/ snapshots_20090422/

Avard, S., Manton, E., English, D., \& Walker, J. (2005). The financial knowledge of college freshmen. College Student Journal, 39(2), 321-339.

Baum, S., \& O'Malley, M. (2003). College on credit: How borrowers perceive their education debt. Journal of Student Financial Aid, 33(3), Article 1. Retrieved from http://publications.nasfaa.org/jsfa/vol33/iss3/1

Baum, S., \& Steele, P. (2010). Who borrows most? Bachelor degree recipients with high levels of student debt. The College Board. Retrieved from http://advocacy. collegeboard.org/sites/default/files/Trends-Who-Borrows-Most-Brief.pdf

Bricker, J., Kennickell, A. B., Moore, K. B., \& Sabelhaus, J. (with Ackerman, S., Argento, R., Fries, G., \& Windle, R. A.). (2012). Changes in U.S. family finances from 2007 to 2010: Evidence from the Survey of Consumer Finances. Federal Reserve Bulletin, 98(2). Retrieved from http://www.federalreserve.gov/Pubs/Bulletin/2012/articles/scf/scf.htm

Bricker, J., \& Thompson, J. (2016). Does education loan debt influence household distress? An assessment using the 2007-2009 Survey of Consumer Finances panel. Contemporary Economic Policy, 34(4), 660-677. doi:10.1111/coep. 12164

Brown, M., \& Caldwell, S. (2013). Young adult student loan borrowers retreat from housing and auto markets. New York, NY: Federal Reserve Bank of New York. 
Brown, M., Haughwout, A., Lee, D., Scally, J., \& van der Klaauw, W. (2014). Measuring student debt and its performance (Staff Report No. 668). Federal Reserve Bank of New York. Retrieved from https://www.newyorkfed.org/ medialibrary/media/research/staff_reports/sr668.pdf

Cha, K. W., Weagley, R. O., \& Reynolds, L. (2005). Parental borrowing for dependent children's higher education. Journal of Family and Economic Issues, 26(3), 299-321. doi:10.1007/s10834-005-5900-y

Chen, H., \& Volpe, R. P. (2002). Gender differences in personal financial literacy among college students. Financial Services Review, 11(3), 289.

Cho, S. H., Xu, Y., \& Kiss, D. E. (2015). Understanding student loan decisions: A literature review. Family and Consumer Sciences Research Journal, 43(3), 229243. doi:10.1111/fcsr.12099

Crissey, S. R. (2009). Educational attainment in the United States: 2007 (Report No. P20-560). Retrieved from http://www.census.gov/prod/2009pubs/p20560.pdf

Cunningham, A. F., \& Kienzl, G. S. (2011). Delinquency: The untold story of student loan borrowing (Report). Washington, DC: Institute for Higher Education Policy. Retrieved from http://www.ihep.org/assets/files/publications/a-f/ delinquency-the_untold_story_final_march_2011.pdf

Despard, M. R., Perantie, D., Taylor, S., Grinstein-Weiss, M., Friedline, T., \& Raghaven, R. (2016). Student loan debt and hardship: Evidence from a large sample of low- and moderate-income households. Children and Youth Services Review, 70, 8-18. doi:10.1016/j.childyouth.2016.09.001

Egoian, J. (2013). 73 will be the retirement norm for millennials. Retrieved from http://www.nerdwallet.com/blog/investing/2013/73-retirement-normmillennials/

Emmons, W. R. (2012, January). Don't expect consumer spending to be the engine of economic growth it once was [online extra]. Regional Economist, 20(1). Retrieved from http://www.stlouisfed.org/publications/re/articles/?id=2201

Fry, R. (2012, September 26). A record one-in-five households now owe student loan debt: Burden greatest on young, poor (Social and Demographic Trends Report). Washington, DC: Pew Research Center. Retrieved from http://www. pewsocialtrends.org/2012/09/26/a-record-one-in-five-households-now-owestudent-loan-debt/

Fry, R., Parker, K., \& Rohal, M. (2014, May 14). Young adults, student debt and economic well-being (Social and Demographic Trends Report). Washington, DC: Pew Research Center. Retrieved from http://www.pewsocialtrends.org/ files/2014/05/ST_2014.05.14_student-debt_complete-report.pdf

Gicheva, D., \& Thompson, J. (2015). The effects of student loans on long-term household financial stability. In B. Hershbein \& K. M. Hollenbeck (Eds.), Student loans and the dynamics of debt (pp. 287-316). Kalamazoo, MI: W.E. Upjohn Institute for Employment Research. doi:10.17848/9780880994873. ch9 
Heckman, S., Lim, H., \& Montalto, C. (2014). Factors related to financial stress among college students. Journal of Financial Therapy, 5(1), 19-39. doi:10.4148/1944-9771.1063

Heflin, C. M., Sandberg, J., \& Rafail, P. (2009). The structure of material hardship in US households: An examination of the coherence behind common measures of well-being. Social Problems, 56(4), 746-764. doi:10.1525/sp.2009. 56.4 .746

Herbst, D. J. (2018). Liquidity and insurance in student loan contracts: Estimating the effects of income-driven repayment on default and consumption. Retrieved from http://conference.iza.org/conference_files/Education_2018/ herbst_d26912.pdf

Hiltonsmith, R. (2013). At what cost? How student debt reduces lifetime wealth (Report). New York, NY: Dēmos. Retrieved from http://www.demos.org/sites/ default/files/publications/AtWhatCostFinal_Demos.pdf

Houle, J. N. (2014). Disparities in debt: Parents' socioeconomic resources and young adult student loan debt. Sociology of Education, 87(1), 53-69. doi: $10.1177 / 0038040713512213$

Houle, J. N., \& Berger, L. (2015) Is student loan debt discouraging homeownership among young adults? Social Service Review, 89(4), 589-621. doi:10.1086/ 684587

Illinois Asset Building Group. (2017). Illinois passes student loan bill of rights. Retrieved from http://illinoisassetbuilding.org/illinois-passes-student-loan-bill-of-rights/

Institute for College Access and Success. (2016). Student debt and the class of 2015. Retrieved from https://ticas.org/sites/default/files/pub_files/classof2015.pdf

Jones, J., \& Schmitt, J. (2014). A college degree is no guarantee. Washington, DC: Center for Economic and Policy Research. Retrieved from http://www.cepr. net/documents/black-coll-grads-2014-05.pdf

Karpman, M., Zuckerman, S., \& Gonzalez, D. (2018). Material hardship among nonelderly adults and their families in 2017. Urban Institute. Retrieved from https://www.urban.org/research/publication/material-hardship-amongnonelderly-adults-and-their-families-2017

Kerby, S. (2013, May 16). Borrowers of color need more options to reduce their student loan debt. Washington, DC: Center for American Progress. Retrieved from http://www.americanprogress.org/issues/race/news/2013/05/16/63533/ borrowers-of-colorneed-more-options-to-reduce-their-student-loan-debt/

Kochhar, R., Fry, R., \& Taylor, P. (2011, July 26). Twenty-to-one: Wealth gaps rise to record highs between Whites, Blacks and Hispanics (Social and Demographic Trends Report). Washington, DC: Pew Research Center. Retrieved from http://www.pewsocialtrends.org/files/2011/07/SDT-Wealth-Report_726-11_FINAL.pdf

McCabe, J., \& Jackson, B. A. (2016). Pathways to financing college: Race and class in students' narratives of paying for school. Social Currents, 3(4), 367-385. doi:10.1177/2329496516636404 
McDaniel, A., Montalto, C. P., Ashton, B., Duckett, K., \& Croft, A. (2014). National student financial wellness study. Retrieved from http://cssl.osu.edu/posts/documents/nsfws-key-findings-report.pdf

Mishory, J., \& O'Sullivan, R. (2012). Denied? The impact of student debt on the ability to buy a house (Report). New York, NY: Young Invincibles. Retrieved from http://younginvincibles.org/wp-content/uploads/2012/08/Denied-TheImpact-of-Student-Debt-on-the-Ability-to-Buy-a-House-8.14.12.pdf

Mottola, G. R. (2014). The financial capability of young adults-A generational view. FINRA Foundation Financial Capacity Insights, Washington, DC. Retrieved from: https://www.finra.org/sites/default/files/14_0100\%201_ IEF_Research\%20Report_CEA_3\%206\%2014\%20\%28FINAL\%29_0_0.pdf

Payea, K., Baum, S., \& Kurose, C. (2013). How students and parents pay for college (Trends in Higher Education Series Analysis Brief). New York, NY: College Board Advocacy and Policy Center. Retrieved from http://trends.collegeboard. $\mathrm{org} /$ sites/default/files/analysis-brief-how-students-parents-pay-college.pdf

Ramirez, E., Ohlhausen, M. K., \& McSweeny, T. (2016). Combating fraud in African American and Latino communities. Federal Trade Commission, Report to Congress. Retrieved from https:/www.ftc.gov/system/files/documents/ reports/combating-fraud-african-american-latino-communities-ftcs-comprehensive-strategic-plan-federal-trade/160615fraudreport.pdf

Ratcliffe, C., \& McKernan, S. M. (2013). Forever in your debt: Who has student debt, and who's worried? (Report) Washington, DC: Urban Institute. Retrieved from http://www.urban.org/UploadedPDF/412849-Forever-in-Your-Debt-WhoHas-Student-Loan-Debt-and-Whos-Worried.pdf

Robb, C. A. (2011). Financial knowledge and credit card behavior of college students. Journal of Family and Economic Issues, 32(4), 690-698. doi:10.1007/ s10834-011-9259-y

Salie Mae. (2016). How America pays for college: Salie Mae's national study of college students and parents. Retrieved from: https://news.salliemae.com/ files/doc_library/file/HowAmericaPaysforCollege2016FNL.pdf

Sanchez, J. M., \& Zhu, L. (2015). Student loan delinquency: A big problem getting worse? Economic Synopses, 7. doi:10.20955/es.2015.7

Shand, J. M. (2007). The impact of early-life debt on the homeownership rates of young households: An empirical investigation (CFR Seminar Paper). Washington, DC: Federal Deposit Insurance Corporation, Center for Financial Research. Retrieved from http://www.fdic.gov/bank/analytical/cfr/2008/jan/CFR_ SS_2008Shand.pdf

Sherraden, M. S. (2010). Financial capacity: What it is, and how can it be created? Center for Social Development, 10, 1-30.

Sinha, G. R., Tan, K., \& Zhan, M. (2018). Patterns of financial attributes and behaviors of emerging adults in the United States. Children and Youth Services Review, 93, 178-185. doi:10.1016/j.childyouth.2018.07.023

Steuerle, E., McKernan, S. M., Ratcliffe, C., \& Zhang, S. (2013). Lost generations? Wealth building among young Americans (Report). Washington, DC: Urbana 
Institute. Retrieved from http://www.urban.org/UploadedPDF/412766-LostGenerations-Wealth-Building-Among-Young-Americans.pdf

Stone, C., Van Horn, C., \& Zukin, C. (2012). Chasing the American dream: Recent college graduates and the great recession (WorkTrends Report). New Brunswick, NJ: Rutgers University, John J. Heldrich Center for Workforce Development. Retrieved from http://www.heldrich.rutgers.edu/sites/default/files/content/ Chasing_American_Dream_Report.pdf

Taylor, P., Fry, R., Cohn, D., Livingston, G., Kochhar, R., Motel, S., \& Patten, E. (2011, November 7). The rising age gap in economic well-being: The old prosper relative to the young (social and demographic trends report). Washington, DC: Pew Research Center. Retrieved from http://www.pewsocialtrends.org/files/2011/11/WealthReportFINAL.pdf

Zhan, M., \& Sinha, G. (2019). Wealth building among young adults with student loan debt: What factors make a difference. Social Development Issues, 41(2), 33-48.

Zhan, M., \& Xiang, X. (2018). Education loans and asset accumulation among Black and Hispanic young adults. Children and Youth Services Review, 91, 121-127. doi:10.1016/j.childyouth.2018.06.006

Zhan, M., Xiang, X., \& Elliott, W. (2016). Education loans and wealth building among young adults. Children and Youth Services Review, 66, 67-75. doi:10.1016/j.childyouth.2016.04.024 